\title{
Local Buckling of Axially Compressed Rectangular Concrete-Filled Steel Tubes
}

\author{
Ruslan Kanishchev ${ }^{1, *}$ and Vincent Kvocak $^{1}$ \\ ${ }^{1}$ Technical University of Kosice, Faculty of Civil Engineering, 04200 Vysokoskolska 4, Kosice, \\ Slovakia
}

\begin{abstract}
The article deals with the theoretical analysis of the local stability of contemporary structures such as rectangular concrete-filled steel tubes (CFST)'s without imperfections. The work presents a numerical method for calculating the coefficient of critical stress by differential equation for slender walls of hollow and concrete filled closed right-angled profiles. The results of the method were compared with the modelled results of the construction elements in ABAQUS software. Based on this theoretical analysis, the direction of future research has been determined, which will focus on the impact of local stability on the cross-section of rectangular CFSTs in terms of their resistance.
\end{abstract}

\section{Introduction}

The construction of civil engineering and transport works increasingly use composite structures formed by joining two effective materials such as steel and concrete. One of the most common examples is concrete filled right-angled (square or rectangular) tubes. These elements have distinct advantages over hollow steel tubes as described in [1-8], but one of the main structural advantages is its significant resistance to loss of local and global stability (which allows designers to reduce the cross-section of the element).

Standards described in $[9,10]$ already exist for the design of the above mentioned structures. However, these standards have limitations in practise such as mechanical properties of materials or the slenderness of steel elements of composite cross-sections etc. Therefore, research should be directed to the enhancement of validity of these standards. Authors such as Mouli and Khelafi [11], Uy [12] investigated the ultimate strength, stability and ductility characteristics of rectangular concrete-filled steel tubes (CFST)'s subjected to axial compression using high performance steels and lightweight concrete aggregates. Experimental tests, conducted by Lee [13], on high-strength concrete-infilled steel tube columns subjected to eccentric loads, showed the influence of width-to-thickness ratio, buckling length-sectional width ratio and eccentricity ratio on the behaviour of these structures. Patel et al. [14] proposed a multiscale numerical model for simulating the interaction of local and global buckling behaviour of eccentrically loaded high strength rectangular CFSTs with large depth-to-thickness ratios. Yang and Han [15] presented research aimed at experimentally investigating the behaviour of rectangular CFSTs loaded

*Corresponding author: ruslan.kanishchev@gmail.com 
axially on a partially stressed cross-sectional area. On the grounds of above mentioned, we noted, that nowadays the direction of research on the development of world standards for the design of composite columns with concrete-filled hollow steel tubes is an actual topic.

\section{Local stability of axially compressed rectangular CFSTs}

Currently, the European Union uses Eurocode 4 to design rectangular CFSTs [16]. The basic disadvantage of the standard is its limitations regarding the slenderness of the wall of rectangular cross-section. The design of more efficient or economical composite structures is driving the research on class 4 hollow steel cross-sections [17] filled with concrete, which already lie beyond the validity of Eurocode 4 .

The basic principles of designing class 4 cross-sections were stipulated by Bryan [18], which offers a critical analysis of the elastic stress $\sigma_{c r}$ for local buckling of long rightangled wall elements with simple (hinge) supports on all the edges acting under the influence of a uniform pressure load. The term stress includes various boundary conditions and distribution of forces over the element with the aid of the coefficient of critical stress $k_{\sigma}$ :

$$
\sigma_{c r}=k_{\sigma} \frac{\pi^{2} E}{12\left(1-v^{2}\right)}\left(\frac{t}{b}\right)^{2}
$$

The minimum values of the coefficient of critical stress $k_{\sigma}$ are stipulated in Eurocode 3 part 1-5 [19]. In the case of internally compressed cross-sections (rectangular tube wall), this coefficient is changed from $k_{\sigma}=4$ for pure pressure until $k_{\sigma}=23.9$ for a combination of compression and bending. The coefficient can be used for hollow rectangular tubes. When the tube is filled with concrete, the standard does not provide a $k_{\sigma}$ value.

The issue regarding the impact of local buckling resistance on thin concrete filled tubes was addressed in the work of [20], that assumed a coefficient of critical stress of $k_{\sigma}=10.3$, which was discovered by Uy and Bradford [21-23] using the finite strip method. However, research work by Timoshenko and Gere [24,25] for changing boundary conditions from simply supported to clamped supports calculated a minimum value of $k_{\sigma}=7$.

\subsection{Stability of simply supported rectangular walls subjected to compression}

The work of [25] povides a differential Germain's equation for a slender wall with a length a, and width b (Fig. 1a), which is simply supported around its perimeter:

$$
C\left(\frac{\partial^{4} w}{\partial x^{4}}+2 \frac{\partial^{4} w}{\partial x^{2} \partial y^{2}}+\frac{\partial^{4} w}{\partial y^{4}}\right)+P \frac{\partial^{2} w}{\partial x^{2}}=0
$$

where $w$ is the deflection of slender walls; $P$ is the compression force.

The cylindrical wall stiffness $C$ :

$$
C=\frac{E t^{3}}{12\left(1-v^{2}\right)}
$$

where $E$ is the modulus of elasticity of the steel; $t$ is the wall thickness; $v$ is the Poisson's ratio. 


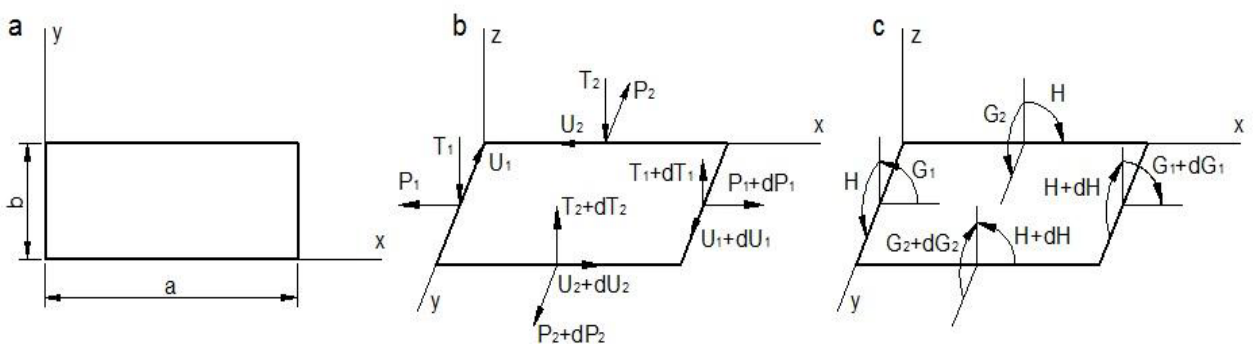

Fig. 1. Mathematical model of slender wall: (a) location of walls in the coordinate axes;

(b) components force in a unit element of the wall; (c) components of the bending moment in a unit element of the wall.

A particular solution of the differential equation (2) represents the balance of forces in one of the possible buckling forms of its walls:

$$
w=A \sin \frac{m \pi x}{a} \sin \frac{n \pi y}{b}
$$

The given solution satisfies the boundary conditions (Fig. 1b,c): for $x=0$ and $x=a \rightarrow$ $w=0$ and $G_{1}=0$; for $y=0$ and $y=b \rightarrow w=0$ and $G_{2}=0$. In addition, the following conditions are fulfilled for stress: $P_{1}=-P ; U_{1}=U_{2}=P_{2}=0$. Compressive force $P$ can be determined by substituting expression (4) to equation (2):

$$
P=C \pi^{2} \frac{\left(\frac{m^{2}}{a^{2}}+\frac{n^{2}}{b^{2}}\right)^{2}}{\frac{m^{2}}{a^{2}}}
$$

where $m$ and $n$ are half-waves along the length (in direction axis X) and across the width (in direction axis Y) of the wall (Fig. 1a).

Of all the possible buckling forms of the balance of force in the cross-section of the wall, we need to find one where the value of the force $\mathrm{P}$ will be minimal, so that the right side of equation (5), reflects the minimum. This will be achieved if $n=1$, naturally, and the value $m$ according to [25] is expressed by equation (6). From the above relationship it follows that the limit value for length $a$, at which the wall reaches its first buckling form, comprises the $m$ half-waves.

$$
a=b \sqrt{m(m+1)}
$$

If we consider that the $P / t=\sigma$, where $\sigma$ is the value of compressive stress, i.e. formula (5) adjustments for $n=1$ and the cylinder wall stiffness are taken as:

$$
\sigma=\left(m \frac{b}{a}+\frac{1}{m} \frac{a}{b}\right)^{2} \frac{\pi^{2} E t^{2}}{12\left(1-v^{2}\right) b^{2}}
$$


According to Eurocode 3 part 1-5 [19] expression (7) is the value of elastic critical stress of the wall $\sigma_{c r}=k_{\sigma} \sigma_{E}$. Thus, the coefficient of critical stress $k_{\sigma}$ is expressed as shown in (Table 1):

$$
k_{\sigma}=\left(m \frac{b}{a}+\frac{1}{m} \frac{a}{b}\right)^{2}
$$

\subsection{Stability of rectangular walls with two unloaded clamped sides and two loaded simply supported sides}

Changing the boundary conditions of walls on the unloaded edges on clamped, requires a different solution of differential equation (2) which takes the shape defined by Timoshenko [25]:

$$
w=A \sin \frac{m \pi x}{a} f(y)
$$

The given solution satisfies the boundary conditions on the transverse edges of the wall (Fig. 1) at $x=0$ and $x=a$. However, an unknown function $f(y)$ must be selected so that it satisfies the boundary condition at the longitudinal edges where $y=0$ and $y=b \rightarrow w=0$ and $\partial w / \partial y=0$ :

$$
f(y)=C_{1} e^{\alpha y}+C_{2} e^{-\alpha y}+C_{3} \cos \beta y+C_{4} \sin \beta y
$$

After considering the above boundary conditions we obtain a transcendental equation (11), the solution of which is used to determine the coefficient of critical stress for a variety of aspect ratios of slender walls (Table 1):

$$
2(1-\cos \beta b \cosh \alpha b)=\left(\frac{\beta}{\alpha}-\frac{\alpha}{\beta}\right) \sin \beta b \sinh \alpha b
$$

\section{The modeling of composite cross sections in ABAQUS software}

The tube walls of hollow and concrete filled rectangular cross-sections which are uniformly compressed at the end edges meet the conditions stipulated in previous two chapters (Fig. 2 ). Therefore, the simulation of 10 samples of empty rectangular steel tubes and 10 samples of concrete-filled rectangular steel tubes was generated in ABAQUS 6.13-4 (Fig.3) to obtain a theoretical comparison of the coefficient of critical stress defined by Timoshenko [25] and identified after modelling values of the elastic critical stress of the walls according to Eurocode 3 part 1-5 [19]. An analysis was carried out on the rectangular cross section of tubes RHS 200x100x3 (Class 4 according to [17]) without imperfections, the length of the column varied between $94 \mathrm{~mm}$ and $263 \mathrm{~mm}$.

When modelling the steel cross-sections the material characteristics defined by Eurocode 3 [17] steel class $S 235$, elastic modulus $E=210 \mathrm{GPa}$, Poisson's ratio in elastic state $v=0.3$ were used. Behaviour of material is modeled as elastoplastic with linear hardening according to EN 1993-1-5. 

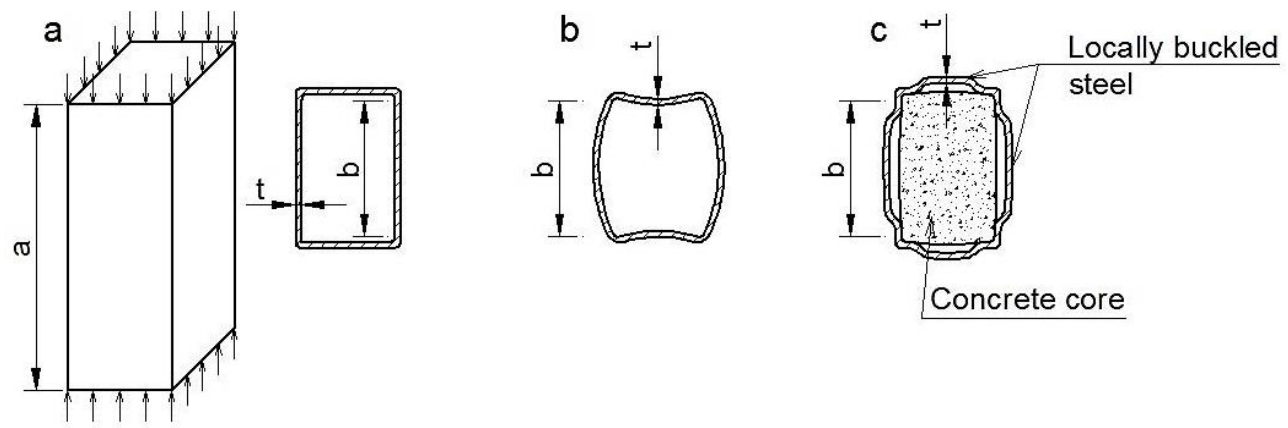

Fig. 2. (a) model of loaded rectangular column; (b) local buckling deformation of the cross-section of the hollow specimen at midpoint of length; (c) local buckling deformation of the cross section of the concrete filled specimen at midpoint of length.

The core of the hollow section was modelled as concrete C20/25 according to Eurocode 2 [26]. A library of ABAQUS elements was used for the modelling: the steel section was made from "shell-type" S4R elements and the concrete core from "solid-type" C3D8 elements. Boundary conditions were simulated so as to correspond to a real experiment. The interaction of the steel and concrete elements was modelled by means of two components: the "normal" one as compression of concrete on the steel section and the "tangential" one as shear resistance at the steel-concrete interface. Loading of columns was modelled as short-term, rising steadily at a constant rate, introduced through the plate of a hydraulic press.

\section{Results and discussion}

The elastic critical stress walls were investigated in the middle of a broader wall of the cross-section upon reaching first buckling form, corresponding to one half-wave (Fig.3-4). The results of comparison are shown in Tab. 1 and Fig. 5.

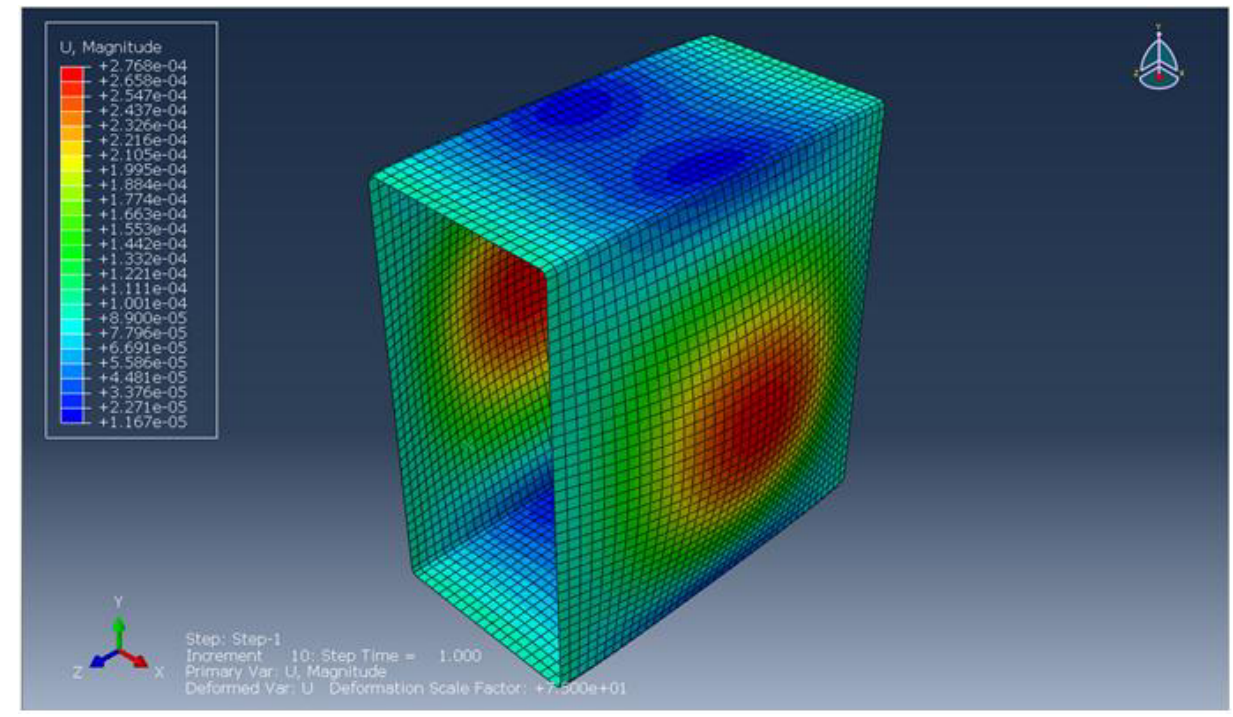

Fig. 3. 3D deformation of the hollow specimen, with length $\mathrm{L}=188 \mathrm{~mm}$ in ABAQUS. 


\section{TPACEE-2016}

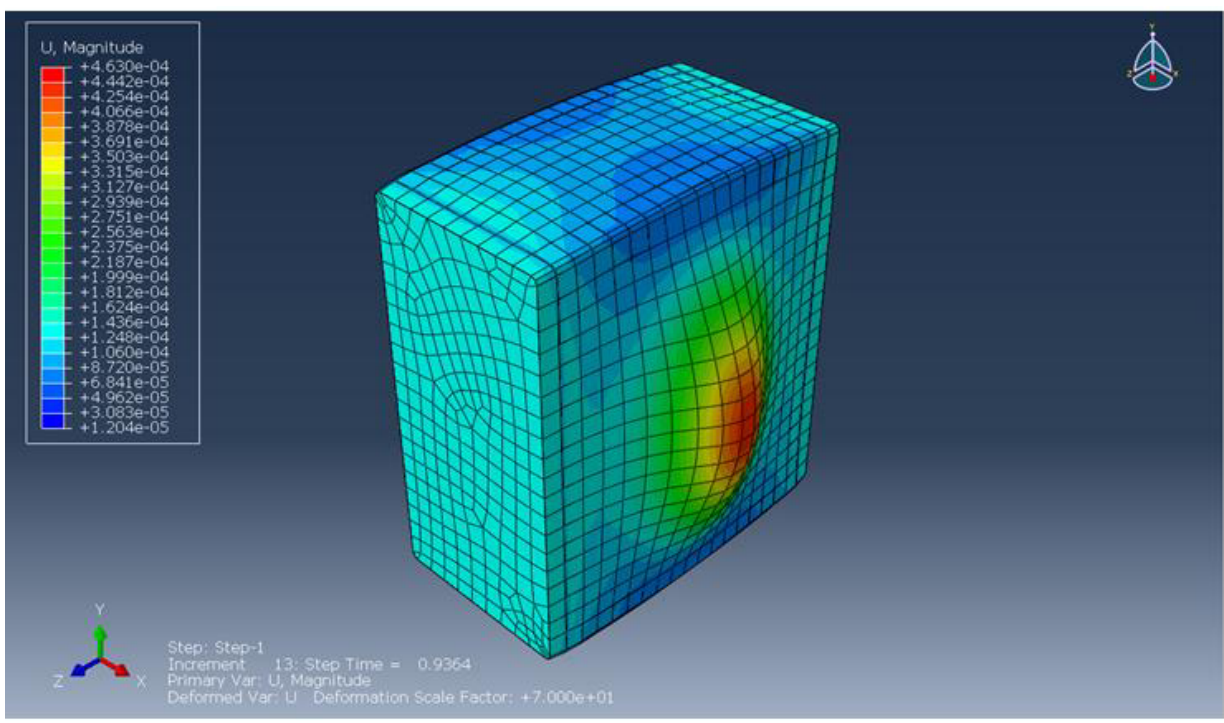

Fig. 4. 3D deformation of the specimen filled with concrete with length $\mathrm{L}=188 \mathrm{~mm}$ in ABAQUS.

The minimum theoretical value for the coefficient of critical stress $k_{\sigma, \min }$ calculated in case of the simply supported walls equals 4 for aspect ratio $a / b=1$ (Fig.4). This value is given in Eurocode 3 part 1-5 [19]. The modelling of hollow rectangular tubes in ABAQUS obtained a minimum value of $k_{\sigma, \min }=4.080$ for aspect ratio $a / b=0.8$, which exceeds the theoretical value of $2 \%$. Therefore, the difference in aspect ratio shows that the modelling considered a rectangular cross section, where, due to various wall stiffness's, stressredistribution was attained.

Table 1. Results of the comparison of coefficients of critical stress.

\begin{tabular}{|c|c|c|c|c|c|c|c|c|c|c|}
\hline \multirow[t]{2}{*}{$\begin{array}{c}\mathrm{a} \\
{[\mathrm{mm}]}\end{array}$} & \multirow[t]{2}{*}{$\begin{array}{c}\mathrm{b} \\
{[\mathrm{mm}]}\end{array}$} & \multirow[t]{2}{*}{$\mathrm{a} / \mathrm{b}$} & \multicolumn{2}{|c|}{$\begin{array}{l}\text { Numerical } \\
\text { calculation } \\
\text { (simply } \\
\text { supported } \\
\text { walls) }\end{array}$} & \multicolumn{2}{|c|}{$\begin{array}{l}\text { Hollow tubes } \\
\text { in ABAQUS }\end{array}$} & \multicolumn{2}{|c|}{$\begin{array}{l}\text { Numerical calculation } \\
\text { (walls with two } \\
\text { unloaded clamped sides } \\
\text { and two loaded simply } \\
\text { supported sides) }\end{array}$} & \multicolumn{2}{|c|}{$\begin{array}{l}\text { CFSTs in } \\
\text { ABAQUS }\end{array}$} \\
\hline & & & $\begin{array}{c}\sigma_{\mathrm{cr}} \\
{[\mathrm{MPa}]}\end{array}$ & $\mathrm{k}_{\sigma}$ & $\begin{array}{c}\sigma_{\mathrm{cr}} \\
{[\mathrm{MPa}]}\end{array}$ & $\mathrm{k}_{\sigma}$ & $\sigma_{\mathrm{cr}},[\mathrm{MPa}]$ & $\mathrm{k}_{\sigma}$ & $\begin{array}{c}\sigma_{\mathrm{cr}} \\
{[\mathrm{MPa}]}\end{array}$ & $\mathrm{k}_{\sigma}$ \\
\hline 94 & \multirow{10}{*}{188} & 0.5 & 270.163 & 6.250 & 221.333 & 5.120 & 332.465 & 7.691 & 220.390 & 5.099 \\
\hline 113 & & 0.6 & 222.086 & .138 & 94.1 & .491 & 305.23 & 78 & 218.834 & 5.063 \\
\hline 132 & & 0.7 & 195.85 & 4.531 & 179.605 & 4.155 & 302.682 & 7.000 & 218.631 & 5.058 \\
\hline 150 & & 0.8 & 181.658 & 4.203 & 176.372 & 4.080 & 315.515 & 7.29 & 218.828 & 5.062 \\
\hline 169 & & 0.9 & 174.831 & 4.045 & 180.315 & 4.171 & 340.212 & 7.871 & 221.521 & 5.125 \\
\hline 188 & & 1.0 & 172.904 & 4.000 & 185.889 & 4.300 & 371.930 & 8.604 & 224.415 & 5.192 \\
\hline 207 & & 1.1 & 174.480 & 4.0 & 197.307 & 4.565 & 4 & 9.494 & 224.490 & 5.193 \\
\hline 226 & & 1.2 & 178.716 & 4.134 & 206.016 & 4.766 & 457.309 & 10.579 & 225.178 & 5.209 \\
\hline 244 & & 1.3 & 185.082 & 4.282 & 223.575 & 5.172 & 507.474 & 11.740 & 225.947 & 5.227 \\
\hline 263 & & 1.4 & 193.230 & 4.470 & 231.203 & 5.349 & 565.755 & 13.088 & 227.399 & 5.261 \\
\hline
\end{tabular}


In the case of CFSTs, a numerical model gives a substantially higher coefficient of critical stress $\left(k_{\sigma, \min }=7.000\right)$ compared to the results obtained by modelling of this elements in ABAQUS $\left(k_{\sigma, \min }=5.058\right)$. Higher values of this coefficient do not permit the use of the numerical model to study the local stability of rectangular CFST cross sections without experimental verification.

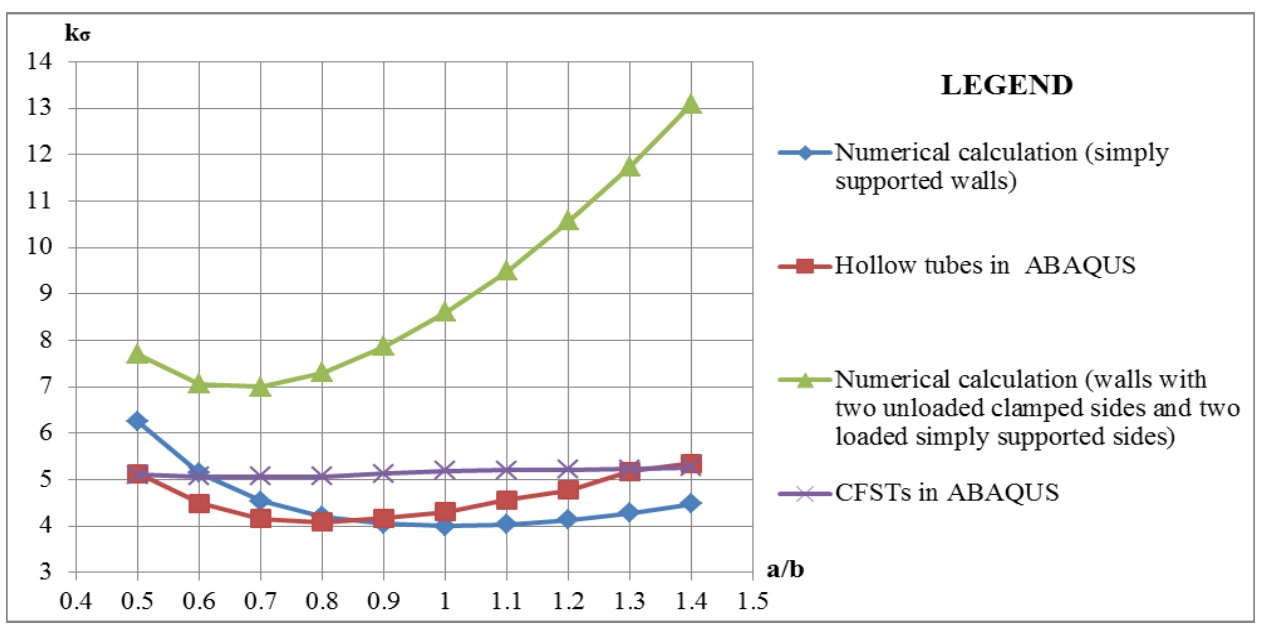

Fig. 5. Comparison of the numerical model to calculate the coefficient of critical stress and results in ABAQUS.

\section{Conclusion}

Based on the results of this work as general conclusions of the research are the following:

1. One of the basic types of composite sections in the form of a rectangular steel tube with a profile of RHS 200x100x3 (EN 10219), filled with concrete, which lie beyond the validity of Eurocode 4, was investigated.

2. Based on modelling of the behavior of the specimens under axial compression in ABAQUS was obtained the theoretical values of the coefficient of critical stress. These coefficients were compared with values, which was obtained by numerical calculation. This comparison shown, that development of the local buckling of the steel part of composite cross-section occurs at a higher value of the coefficient of elastic critical stress in comparison with normative data EN 1993-1-5 for tubes, not filled with concrete.

3. Based on the above theoretical analysis the direction for further research was chosen aimed at the development of numerical methods for calculating the coefficient of critical stress by differential equations of slender wall rectangular CFSTs.

\section{Acknowledgements}

The paper presented was supported by the projects: VEGA 1/0188/16 "Static and Fatigue Resistance of Joints and Members of Steel and Composite Structures" of the Scientific Grant Agency of the Ministry of Education, science, research and sport of the Slovak Republic and the Slovak Academy of Sciences. 


\section{References}

1. R. Kanishchev, V. Kvočák, Vedecko-výskumná činnost’ UIS 2013, 107-116, (2014)

2. V. Kvočák, G. Varga, R. Vargova, Proc. Eng. 40, 469-474 (2012)

3. A. Duricová, M. Rovňák, Navrhovanie ocel'ovo - betónových konštrukcií (VEDA, Bratislava, 2008)

4. J. Kozák, Š. Gramblička, J. Lapos, Spriahnuté a kombinované ocelobetónové konštrukcie pozemných stavieb (Jaga, Bratislava, 2000)

5. A. Kikin, R. Sanžarovskiy, V. Trul, Konstruksii iz stalnykh trub, zapolnennykh betonom [Construction of steel tubes filled with concrete] (Stroyizdat, Moscow, 1974)

6. L. Storoženko, P. Plachotny, A. Černiy, Raschet trubobetonnykh konstruktsiy (Budivelnik, Kiev, 1991)

7. O. Oniščenko, S. Pičugin, V. Oniščenko, O. Semko, L. Storoženko, I. Emelanova, O. Landar, Vysokoefektivni tekhnologii ta kompleksnye konstruktsii v budivnitstvi (Formika, Poltava, 2009)

8. I. Garanzha, N. Vatin, J. Appl. Mech. and Mat. 633-634, 965-971 (2014)

9. R. Kanishchev, V. Kvočák, IABSE Elegance in Str. Nara, 1-8 (2015)

10. W.-H. Kang, B. Uy, Z. Tao, S. Hicks, J. Advanced Steel Constr., 11 (2), 165-184 (2015)

11. M. Mouli, H. Khelafi, J. Eng. Str., 29, 1791-1797 (2007)

12. B. Uy, J. of Constr. Steel res., 64, 748-754 (2008)

13. S. Lee, J. Steel and Comp. Str., 7(2), 135-160 (2007)

14. V. I. Patel, Q. Q. Liang, M. Hadi, J. Inter. and M. M., 5(2), 91-104 (2012)

15. Y.Yang, L. Han, J. of Constr.Steel Res., 65, 1617-1630 (2009)

16. EN 1994-1-1, Eurocode 4: Design of composite steel and concrete structures. Part 1-1: General rules and rules for buildings (CEN, Brussels, 2004)

17. EN 1993-1-1, Eurocode 3: Design of steel structures. Part 1-1: General rules and rules for buildings (CEN, Brussels, 2005)

18. G. H. Bryan, Proc. of the London Mathem. Soc., 22, 54-67 (1891)

19. EN 1993-1-5, Eurocode 3: Design of steel structures. Part 1-5: Plated structural elements (CEN, Brussels, 2008)

20. D.A. Nethercot, Composite construction (Spon press, New Yourk, 2004)

21. B. Uy, J. of Constr. Steel Res., 47, 47-72 (1998)

22. B. Uy, M.A. Bradford, Fifth intern. Conf. on steel struct. Jakarta, 313-322 (1994)

23. M.A. Bradford, D.J. Oelhers, Composite steel and concrete structural members, Fundamental behaviour (Pergamon, London, 1995)

24. S.P. Timoshenko, J.M. Gere, Theory of elastic stability (McGraw- Hill, New York, 1961)

25. S.P. Timoshenko, Ustoychivost' sterzhney, plastin i obolochek (Nauka, Moscow, 1971)

26. 1992-1-1, Eurocode 2: Design of concrete structures. Part 1-1: General rules and rules for buildings (CEN, Brussels, 2005) 